\title{
Inhibition Effect of Fluoride Ion on Corrosion of 304 Stainless Steel in Occluded Cell Corrosion Stage in the Presence of Chloride Ion
}

\author{
Zhengwei Luo, Jie Zuo, Hui Jiang, Wenhua Geng, Yongzhang Zhou, Zhouyang Lian * and Wuji Wei *D \\ School of Environmental Science and Engineering, Nanjing Tech University, 30\# Puzhu South Road, \\ Nanjing 211816, China; luozw2015@njtech.edu.cn (Z.L.); 201961202025@njtech.edu.cn (J.Z.); \\ huijiang@njtech.edu.cn (H.J.); gengwenhua@njtech.edu.cn (W.G.); zhouyongzhang@njtech.edu.cn (Y.Z.) \\ * Correspondence: lianzy@njtech.edu.cn (Z.L.); wjwei@njtech.edu.cn (W.W.)
}

Citation: Luo, Z.; Zuo, J.; Jiang, H.; Geng, W.; Zhou, Y.; Lian, Z.; Wei, W. Inhibition Effect of Fluoride Ion on Corrosion of 304 Stainless Steel in Occluded Cell Corrosion Stage in the Presence of Chloride Ion. Metals 2021, 11, 350. https://doi.org/10.3390/ met11020350

Academic Editors: Hannu Hänninen and Eric Hug

Received: 15 December 2020

Accepted: 12 February 2021

Published: 19 February 2021

Publisher's Note: MDPI stays neutral with regard to jurisdictional claims in published maps and institutional affiliations.

Copyright: (C) 2021 by the authors. Licensee MDPI, Basel, Switzerland. This article is an open access article distributed under the terms and conditions of the Creative Commons Attribution (CC BY) license (https:// creativecommons.org/licenses/by/ $4.0 /)$.

\begin{abstract}
The role of $\mathrm{F}^{-}$in the corrosion of stainless steel at the stage of occluded cell corrosion in a mixture of chloride, fluoride, and sulfate ions was investigated. A simulated occluded corrosion cell was designed using an elaborate simulated rust layer. Composite electrodes were used to monitor the variation of the concentration of ions, $\mathrm{pH}$, and dissolved oxygen of the occluded solution. The results show that the influence of $\mathrm{F}^{-}$on the corrosion of 304 stainless steel, in the occluded cell corrosion stage, is concentration dependent. When the $\mathrm{F}^{-} / \mathrm{Cl}^{-}$ratio is higher than 2 , the corrosion can be significantly suppressed. Analyses showed that the corrosion inhibition effect could be attributed to the migration of $\mathrm{F}^{-}$to the occluded cell, which can reduce the migration of $\mathrm{Cl}^{-}$, dampen the decrease in $\mathrm{pH}$, and react with metal ions to form semi-soluble products. Meanwhile, the influence of $\mathrm{F}^{-}$on the corrosion process was also verified using drilled stainless steel specimens, demonstrating the practicality and validity of the simulated occluded cell corrosion model.
\end{abstract}

Keywords: localized corrosion; occluded corrosion cell; stainless steel; fluoride; corrosion inhibition

\section{Introduction}

Ammonia desulphurization is a widely used flue gas desulphurization technique with an absorption efficiency of $\mathrm{SO}_{2}$ higher than $95 \%$, which can also produce low-cost ammonium sulfate fertilizer. During the desulfurization process, $\mathrm{F}^{-}$and $\mathrm{Cl}^{-}$produced from coal-burning are accumulated in the desulfurization slurry, forming a typical $\mathrm{F}^{-}$and $\mathrm{Cl}^{-}$mixture system [1-3]. The corrosion of the desulphurization equipment caused by the existence of $\mathrm{Cl}^{-}$can severely hinder its application for ammonia desulphurization. Austenite stainless steel, with a Cr oxide film on its surface, is more corrosion resistant than carbon steel and is commonly used for industrial processes [4,5]. However, the application of stainless steel for ammonia desulphurization is rare, since the high concentration of $\mathrm{Cl}^{-}$in the desulfurization slurry can cause severe localized corrosion of the stainless steel, such as pitting corrosion, crevice corrosion, underscale corrosion, and stress corrosion cracking [6,7]. It has been reported that $\mathrm{F}^{-}$has a certain inhibitory effect on stainless steel corrosion under the coexistence of $\mathrm{F}^{-}$and $\mathrm{Cl}^{-}$[8]. Studies showed that a mixture of $\mathrm{F}^{-}$and $\mathrm{Cl}^{-}$, with a $\mathrm{F}^{-}$to $\mathrm{Cl}^{-}$molar ratio of 7 to 10 , respectively, the crevice corrosion of the alloy 22 was completely inhibited [9]. Wang et al. found that $\mathrm{F}^{-}$and $\mathrm{Cl}^{-}$had a synergistic effect in initiating uniform corrosion of stainless steel, which was related to the concentration of both ions [10]. At present, studies on the corrosion of stainless steel in contact with mixed ion system containing $\mathrm{F}^{-}$and $\mathrm{Cl}^{-}$mainly focus on uniform corrosion [11], localized corrosion initiation [12], $\mathrm{pH}$ and ion concentration changes in corrosion areas [13-15]; while the influence of $\mathrm{F}^{-}$on localized corrosion in the stage of occluded cell corrosion and mechanism are seldom reported.

Occluded cell corrosion is a typical propagation stage of localized corrosion, such as pitting corrosion, crevice corrosion, stress corrosion cracking, and underscale corrosion. 
Due to the acidizing autocatalytic phenomena, the occluded cell corrosion process has an obvious accelerating effect [16]. Simulated occluded cell models provide an important tool for studying the development stage of localized corrosion since it was proposed in $1970[17,18]$. The current models of simulated occluded cells generally adopt the lowefficiency off-line measurement methods for ions, which make it difficult to obtain the $\mathrm{pH}$ and ion concentration simultaneously and immediately [13-15,19]. On-line monitoring of $\mathrm{pH}$ and $\mathrm{Cl}^{-}$concentration with microelectrodes has been greatly improved [20-22]. Yan et al. integrated an iridium electrode and $\mathrm{Ag} / \mathrm{AgCl}$ electrode together to form a microelectrode for monitoring the $\mathrm{pH}$ and $\mathrm{Cl}^{-}$concentration for crevice corrosion [23]. Zhu et al. used a saturated calomel electrode combined with an antimony and $\mathrm{Ag} / \mathrm{AgCl}$ electrode to measure $\mathrm{pH}$ and $\mathrm{Cl}^{-}$concentration in the occluded area, respectively [24]. At present, $\mathrm{pH}$ and $\mathrm{Cl}^{-}$monitoring electrodes are generally three-electrode systems which cannot work continuously for a long time, and the measured ion concentration range is limited. Meanwhile, no online monitoring of $\mathrm{F}^{-}$has been reported in simulated occluded cells.

Compared with the inhibition of uniform corrosion and localized corrosion initiation, the inhibition of the propagation process is also helpful to alleviate the damage caused by corrosion. When localized corrosion is in the stage of occluded cell corrosion, the addition of a corrosion inhibitor has a negligible inhibitory effect on the development of the internal corrosion in the occluded area. Since the sealing rust layer on the localized corrosion area is very tight, $\mathrm{Cl}^{-}$, with its small ionic radius, can enter the occluded area from the external solution through the rust layer, while other ions including, $\mathrm{O}_{2}$ molecules, are difficult to pass through. Zhu et al. simulated the sealing rust layer for the underscale corrosion of $\mathrm{N} 80$ steel with iron oxides and studied the influence of $\mathrm{C}_{12} \mathrm{H}_{23} \mathrm{O}_{2}{ }^{-}$on the development of the occluded cell [25]. The results showed that $\mathrm{C}_{12} \mathrm{H}_{23} \mathrm{O}_{2}{ }^{-}$reduces $\mathrm{Cl}^{-}$migration by making the scale layer cationic-selective; thus, reducing the corrosion in the occluded area. However, from the point of view of the hydrated ion radius and charge, such ions are less likely to enter the occluded area through the rust layer or pitting pit surface seals. For $\mathrm{F}^{-}$, whose ionic radius is close to that of $\mathrm{Cl}^{-}$but is more electronegative than $\mathrm{Cl}^{-}$, it is possible to enter the occluded area through the rust layer.

In view of the development process of local corrosion of stainless steel in contact with an $\mathrm{F}^{-}$and $\mathrm{Cl}^{-}$coexistence system, exploring the role of $\mathrm{F}^{-}$in the localized corrosion of stainless steel is relevant for exploring the applicability of stainless steel and solving corrosion problems of the equipment. In this paper, based on the ammonia desulphurization slurry as the case study, a simulated occluded cell device was constructed to achieve long-duration on-line monitoring of $\mathrm{pH}$, the concentration of ions, and dissolved oxygen concentration. The effect of $\mathrm{F}^{-}$on the corrosion current of the occluded corrosion cell under the coexistence of two kinds of halogen ions was studied, mainly from the perspective of corrosion current, $\mathrm{pH}$ change of the solution in the occluded area, the reaction of $\mathrm{F}^{-}$on the surface of stainless steel, and the binding form of $\mathrm{F}^{-}$with metal ions. Furthermore, drilled stainless specimens were used to simulate the occluded area of localized corrosion, the influence of $\mathrm{F}^{-}$on the development of corrosion was analyzed, and the results were compared with those of the simulated occluded corrosion cell model.

\section{Materials and Methods}

\subsection{Reagents and Materials}

Ammonium sulfate, ammonium chloride, ammonium fluoride, and other reagents were analytical pure, purchased from Sinopharm Group Chemical Reagents Co., LTD, Shanghai, China. AISI 304 austenitic stainless steel was used, and the composition is shown in Table 1. The stainless steel specimens are ground to 800 mesh, step by step by silicon carbide sandpaper, cleaned repeatedly with acetone and ethanol, rinsed with deionized water, dried by cold air and placed in a desiccator for $24 \mathrm{~h}$, and weighed before use. 
Table 1. Nominal chemical compositions of the tested 304 stainless steel (wt.\%).

\begin{tabular}{cccccccc}
\hline $\mathbf{C r}$ & $\mathbf{N i}$ & $\mathbf{C}$ & $\mathbf{S}$ & $\mathbf{S i}$ & $\mathbf{M n}$ & $\mathbf{P}$ & $\mathbf{F e}$ \\
\hline 18.23 & 8.10 & 0.04 & 0.002 & 0.35 & 1.10 & 0.036 & Balanced \\
\hline
\end{tabular}

\subsection{Simulated Occluded Corrosion Cell and Experimental Methods}

The experimental device of the simulated corrosion cell is shown in Figure 1. The volume of the cylindrical occluded area is $150 \mathrm{~mL}$, and the volume of the external solution is $10 \mathrm{~L}$. The internal electrode is composed of 304 stainless steel with a size of $10 \mathrm{~mm} \times 10 \mathrm{~mm} \times 2 \mathrm{~mm}$, and an exposed area of $1.6 \mathrm{~cm}^{2}$. The external electrode is 304 stainless steel, and the exposed area is 10 times larger than the external electrode. The counter electrode is a platinum electrode of size $10 \mathrm{~mm} \times 10 \mathrm{~mm} \times 0.2 \mathrm{~mm}$, and an $\mathrm{Ag} / \mathrm{AgCl}$ electrode is used as the reference electrode. The potential values in this paper were all relative to $\mathrm{Ag} / \mathrm{AgCl}$ electrode unless otherwise stated. The applied current is provided by a potentiostat (DJS 292B, Shanghai Xinrui Instrument Co., LTD, Shanghai, China). The internal electrode is the anode, and the external electrode is the cathode. The diameter of the ion migration channel is about $7 \mathrm{~mm}$, and the details about the simulated rust layer are shown in Figure 1. The simulated rust layer used in the experiment is a mixture of mixed iron oxide $\left(65 \% \mathrm{Fe}_{2} \mathrm{O}_{3}, 25 \% \mathrm{Fe}_{3} \mathrm{O}_{4}\right.$, and $10 \% \mathrm{Fe}(\mathrm{OH})_{3}$, wt $)$ and calcium sulfate with a mass ratio of 9:1, carried on filter paper, and agar $(0.5 \%)$ is used to shape and fix the mixture.
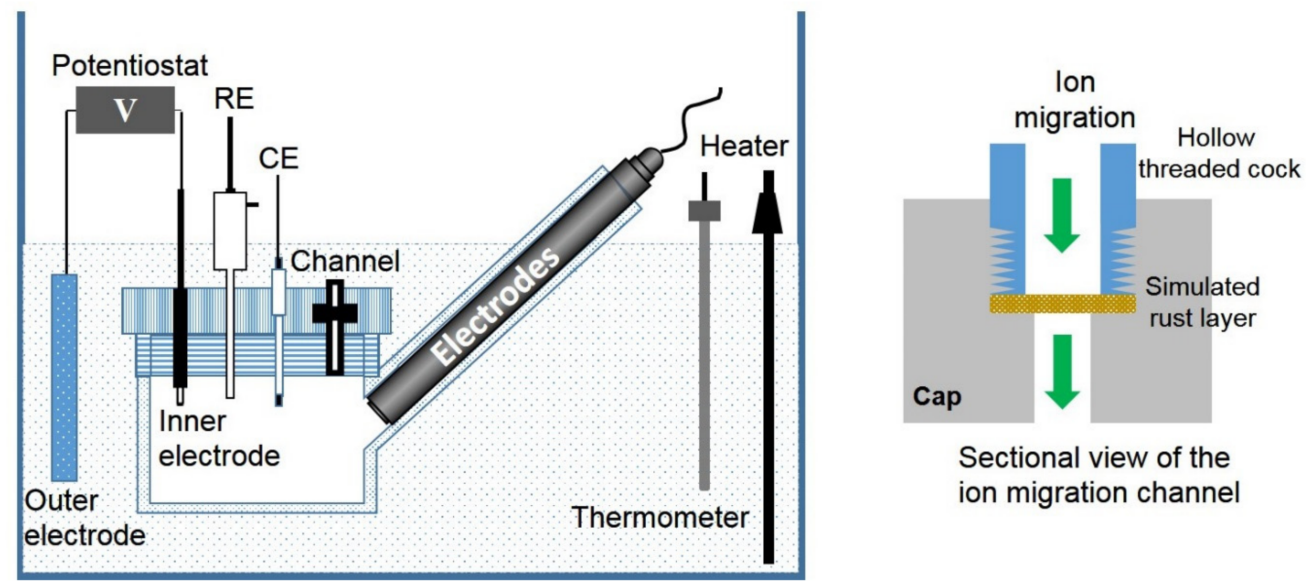

Figure 1. Experimental apparatus of the simulated occluded cell and the sectional view of the ion migration channel.

The simulated corrosion cell is immersed in a plexiglass container containing the experimental solution at a controlled temperature of $40^{\circ} \mathrm{C}$. The occluded cell is made of plexiglass, with four oblique intubations on the side wall for the insertion of online fluoride and chloride monitoring electrode, a pH electrode, and a dissolved oxygen electrode. The on-line halogen ion monitoring electrodes and $\mathrm{pH}$ electrode are purchased from Shanghai Boqu Instrument Co., LTD., Shanghai, China, and the dissolved oxygen electrode is purchased from Shanghai Renshi Electronics Co., LTD, Shanghai, China. Paperless recorders are used to record the concentration and $\mathrm{pH}$ changes. The online monitoring data can be verified by offline detection, in which the $\mathrm{pH}$ of the solution is detected by the $\mathrm{pH}$ meter, and the concentration of fluoride and chloride is measured by the ion selective electrode method and the potentiometric titration method, respectively [26,27]. 
X-ray photoelectron spectroscopy (XPS, PHI 5000 VersaProbe, Ulvac-Phi, Kanagawa, Japan) was used to analyze surface elements of the specimens. When weighing the internal electrode specimens, the corrosion products were rinsed with deionized water, then washed successively with hydrochloric acid solution (hydrochloric acid and distilled water with a volume ratio of 1:4) containing $0.5 \%$ ullotropine and scrubbed with $60 \mathrm{~g} / \mathrm{L}$ sodium hydroxide solution. Then they were cleaned successively with deionized water, anhydrous ethanol, and acetone. After being blown dry by cold air, they were placed in a desiccator for $24 \mathrm{~h}$ and then weighed.

\subsection{Simulation of Occluded Cell Corrosion Using Drilled Specimens}

The 304 stainless steel specimens $(50 \mathrm{~mm} \times 25 \mathrm{~mm} \times 6 \mathrm{~mm})$ are drilled by a computerbased numerical control machine tool after polishing and cleaning, with an aperture of $2 \mathrm{~mm}$ and a depth of $4.5 \mathrm{~mm}$, each. The distribution of holes is shown in Figure 2. After cleaning and drying, mercury is dropped into the hole, and the quality difference before and after dropping is calculated. Then, the density of mercury is divided to get the volume of the hole. Solutions with different concentrations of $\mathrm{F}^{-}$and $\mathrm{Cl}^{-}$are injected into the drilled holes. A simulated rust layer, with a radius larger than that of the holes, is first covered over the holes, and then, a layer of filter paper with a larger radius is fixed on the outer layer with epoxy glue to fix the simulated rust layer. The simulated rust layer is elaborated in the same way as that of the occluded cell. Solutions containing $\mathrm{F}^{-}$and $\mathrm{Cl}^{-}$are poured into the experimental container. After the solution temperature reached $40{ }^{\circ} \mathrm{C}$, the stainless steel specimens are put into the solution. After a certain period, the volume of the holes is measured by dropping mercury, and the corrosion development is characterized according to the volume changes before and after the experiment. At least five values were measured and averaged to get the volume change of the holes.

\section{Front view}

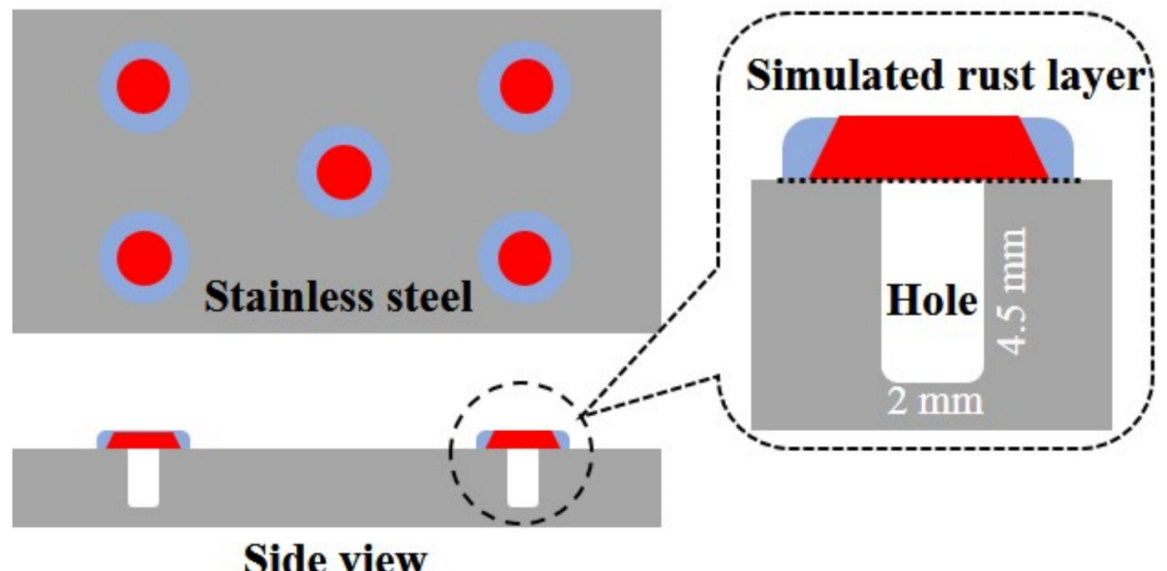

Figure 2. Schematic diagram of drilled 304 stainless steel specimens for simulating of occluded cell corrosion.

\section{Results and Discussion}

\subsection{Reliability of Simulated Occluded Corrosion Cell}

\subsubsection{Thickness of Simulated Rust Layer}

The simulated rust layer as the ion migration channel directly affects the ion migration from the external solution to the occluded area. Simulated rust layers, with thicknesses of $1,2,3$, and $4 \mathrm{~mm}$, were used to investigate the influence of different simulated rust layer thicknesses on the ion migration. The primary solution is a $\left(\mathrm{NH}_{4}\right)_{2} \mathrm{SO}_{4}$ solution $(0.5 \%$, wt $)$, to which $\mathrm{NH}_{4} \mathrm{Cl}(0.05 \mathrm{~mol} / \mathrm{L})$ and $\mathrm{NH}_{4} \mathrm{~F}(0.05 \mathrm{~mol} / \mathrm{L})$ were added. 
As shown in Figure 3, The migration of $\mathrm{SO}_{4}{ }^{2-}$ is much higher than that of $\mathrm{F}^{-}$and $\mathrm{Cl}^{-}$ when a filter paper is used to simulate the rust layer. Since $\mathrm{SO}_{4}{ }^{2-}$ is divalent ions, it migrates into the occluded area in preference to $\mathrm{F}^{-}$and $\mathrm{Cl}^{-}$. Filter paper has no ion selectivity, so the migration of $\mathrm{SO}_{4}{ }^{2-}$ is the largest. The $\mathrm{pH}$ value of the final occluded solution is 5.64, which is slightly lower than the initial $\mathrm{pH}$ value, and no obvious acidification effect is shown. On the one hand, this is due to the limited $\mathrm{Cl}^{-}$migration, on the other hand, the sealing effect of filter paper is not good, and a complete occluded area is not formed. With the increase of the thickness of the simulated rust layer, the migration of $\mathrm{SO}_{4}{ }^{2-}$ tends to decrease, indicating the enhancement of repulsion of $\mathrm{SO}_{4}{ }^{2-}$ by the simulated rust layer. The measured zeta potential of the simulated rust layer is $-16.47 \mathrm{mV}$, indicating that it has a certain electrostatic repulsion effect for anions. Since the valence state of divalent $\mathrm{SO}_{4}{ }^{2-}$ is higher than that of monovalent $\mathrm{F}^{-}$and $\mathrm{Cl}^{-}$, the electrostatic repulsion to $\mathrm{SO}_{4}{ }^{2-}$ is stronger for the rust layer. With the decreased migration of $\mathrm{SO}_{4}{ }^{2-}$, the migration of $\mathrm{F}^{-}$and $\mathrm{Cl}^{-}$tends to increase slightly. In addition, the final $\mathrm{pH}$ of the solution in the occluded cell decreases gradually with the increase of the simulated rust layer thickness, indicating that the simulated rust layer has a good sealing effect; thus, acidifying the occluded solution. Since the migrated ions and solution $\mathrm{pH}$ tend to be stable when the thickness was higher than $3 \mathrm{~mm}$, rust layers with thicknesses of $3 \mathrm{~mm}$ were used in the following experiments.

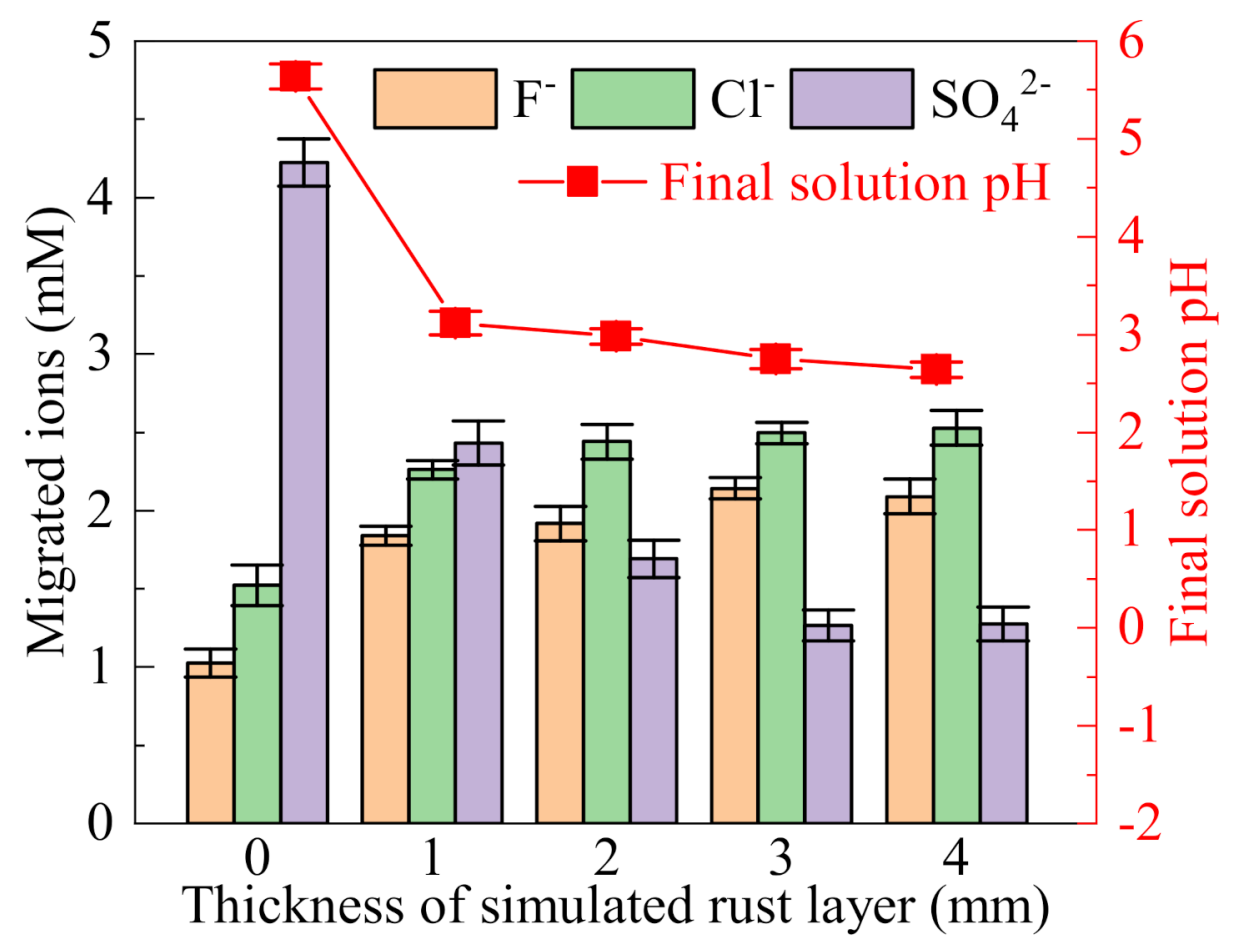

Figure 3. Influence of the thickness of the simulated rust layer on the migration of ions and final $\mathrm{pH}$ of the occluded solution (( $\left.\mathrm{NH}_{4}\right)_{2} \mathrm{SO}_{4}\left(0.5 \%\right.$, wt), $\left.\mathrm{NH}_{4} \mathrm{Cl}(0.05 \mathrm{~mol} / \mathrm{L}), \mathrm{NH}_{4} \mathrm{~F}(0.05 \mathrm{~mol} / \mathrm{L})\right)$.

\subsubsection{Stability of Online Monitoring Electrodes}

Online monitoring electrodes are important to obtain ion concentration and $\mathrm{pH}$ of the occluded solution, so their stability and precision should be guaranteed. Composite electrodes, each based on $\mathrm{F}^{-}$and $\mathrm{Cl}^{-}$, and a $\mathrm{pH}$ electrode were calibrated with a mixed standard solution containing $\mathrm{Cl}^{-}, \mathrm{F}^{-}$, and $\mathrm{SO}_{4}{ }^{2-}$ and were used to measure the ion concentration and $\mathrm{pH}$ in the occluded area over a long duration. As shown in Figure 4, the measured data were very stable during the long operation of the electrodes. The measured $\mathrm{F}^{-}$concentration is slightly lower than the real value because the activity of $\mathrm{F}^{-}$ can be affected by other ions, causing the measured value of $\mathrm{F}^{-}$to decrease. The measured $\mathrm{Cl}^{-}$concentration is slightly higher than the real value, and $\mathrm{pH}$ value increases slightly 
over time. However, the deviation of all three parameters is less than 3\%. Therefore, these electrodes, calibrated with the mixed standard solution, can eliminate the mutual interferences between the co-existing ions and achieve long-term online monitoring of ion concentration and $\mathrm{pH}$ in the occluded solution.

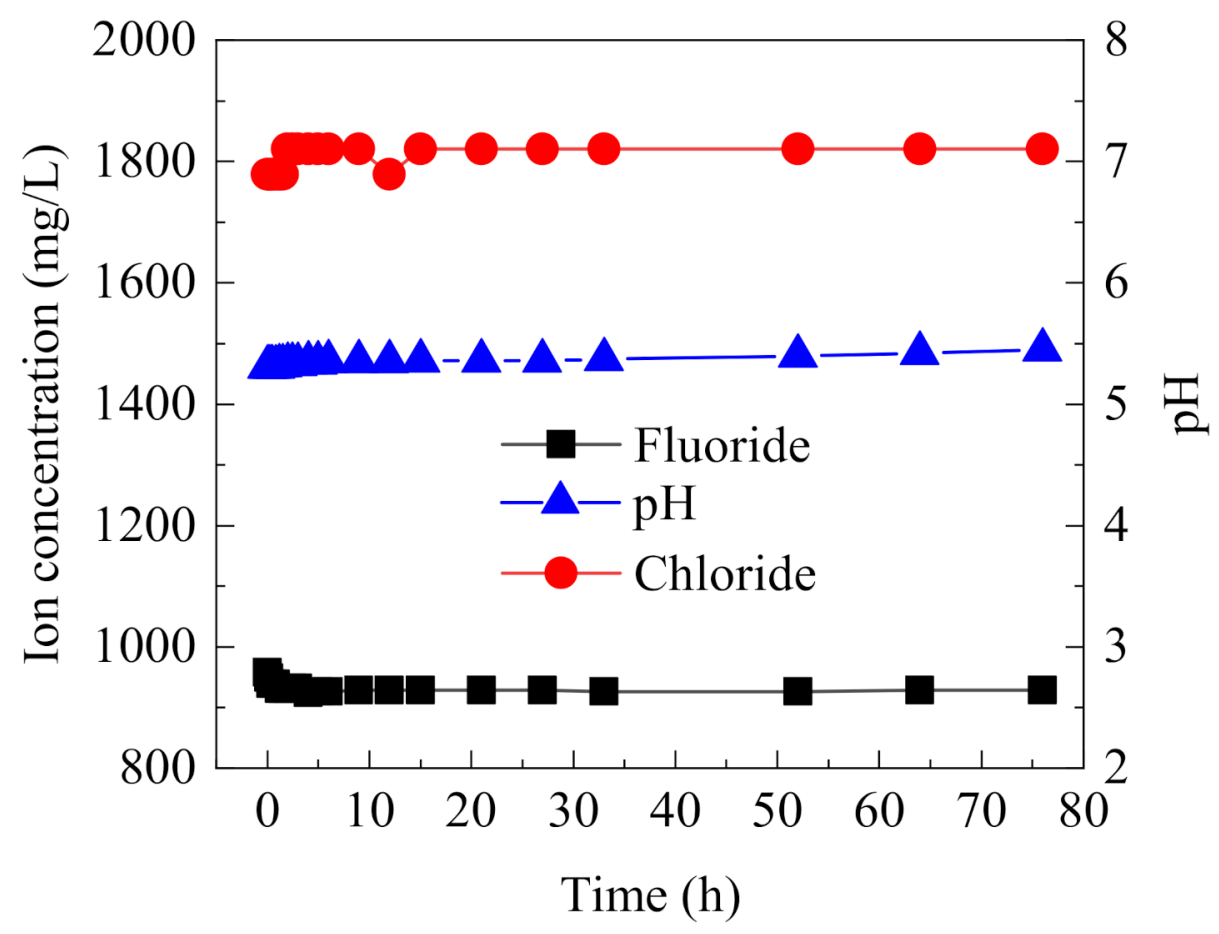

Figure 4. Long-term stability for the online monitoring of $\mathrm{F}^{-}, \mathrm{Cl}^{-}$, and $\mathrm{pH}$ using composite electrodes.

\subsubsection{Simulation of the Development of the Occluded Corrosion Cell}

To evaluate the operation reliability of the established occluded corrosion cell, a 72-h long continuous experiment, under a voltage of $0.4 \mathrm{~V}$ was conducted, and the variation of parameters obtained is shown in Figure 5. The dissolved oxygen was almost completely consumed in the first $3 \mathrm{~h}$, and the oxygen-free environment in the occluded area could be well simulated [28]. The corrosion current was low and showed a slow and steady rise at the beginning. After $40 \mathrm{~h}$, the current began to decline, and the $\mathrm{pH}$ gradually decreased to 4.6. The $\mathrm{Cl}^{-}$concentration increased slowly in the first $30 \mathrm{~h}$, then increased rapidly, and gradually stabilized after $60 \mathrm{~h}$. In the initial stage, $\mathrm{Cl}^{-}$began to enter the occluded solution, and was not sufficient to start corrosion. With more $\mathrm{Cl}^{-}$entering the occluded solution, the $\mathrm{pH}$ value of the solution decreased rapidly due to acidification autocatalysis, and the $\mathrm{Cl}^{-}$concentration increased rapidly. In general, the development of the occluded cell is in line with the acidizing autocatalysis principle, which indicates that the model can simulate the development of occluded corrosion cell during localized corrosions [14,24]. 

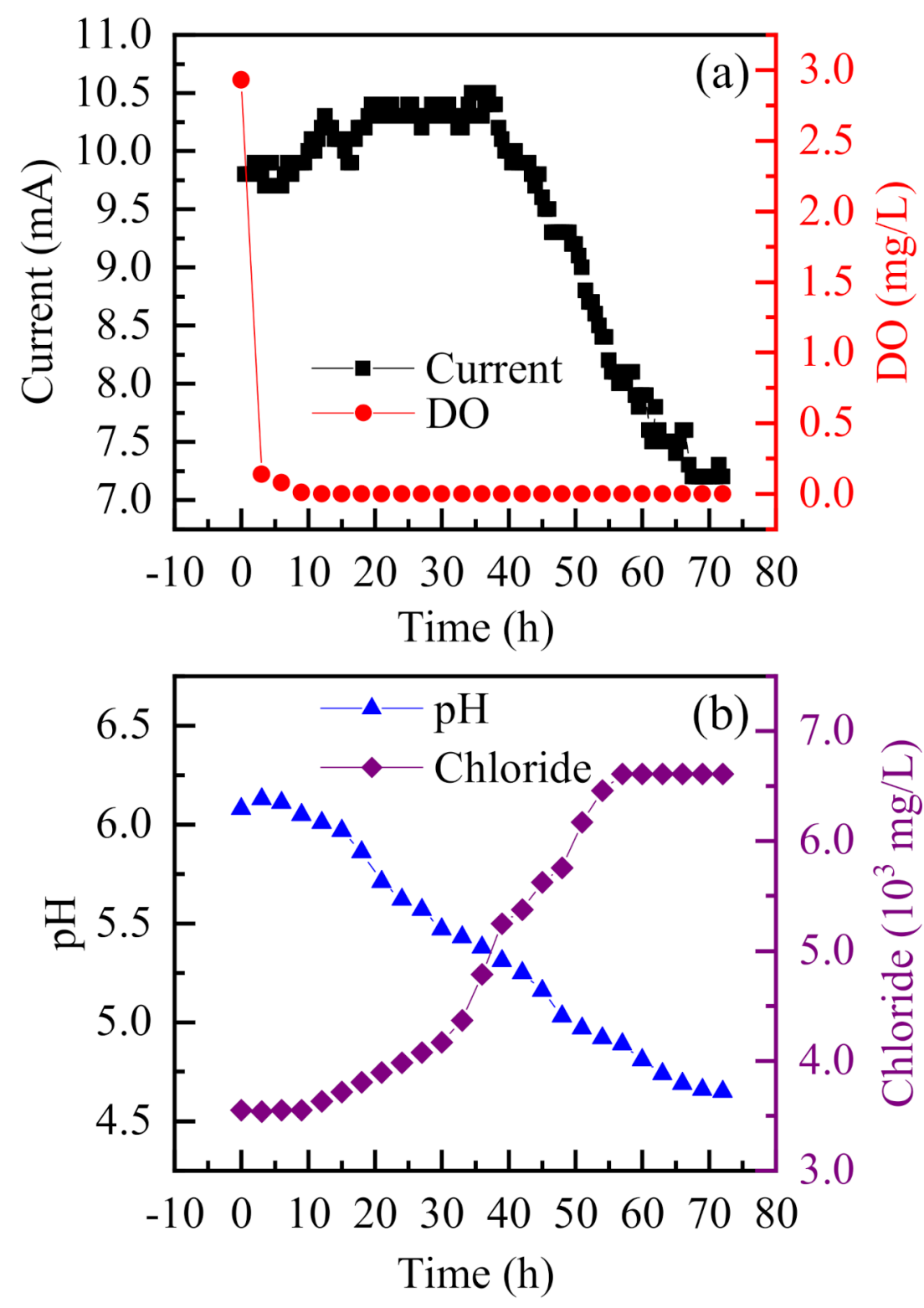

Figure 5. Variations of current, dissolved oxygen, solution $\mathrm{pH}$, and $\mathrm{Cl}^{-}$concentration with long duration $\left(\left(\mathrm{NH}_{4}\right)_{2} \mathrm{SO}_{4}\right.$ solution $(0.5 \%$, wt $\left.), \mathrm{NH}_{4} \mathrm{Cl}(0.1 \mathrm{~mol} / \mathrm{L}), \mathrm{NH}_{4} \mathrm{~F}(0.1 \mathrm{~mol} / \mathrm{L})\right)$.

\subsection{Influence of $\mathrm{F}^{-}$on the Development of Occluded Cell Corrosion}

\subsubsection{Influence of $\mathrm{F}^{-}$on Corrosion Current}

Current is an indicator for the development of occluded cell corrosion, and higher current value demonstrates the rapid evolution of occluded area. To investigate the influence of $\mathrm{F}^{-}$on the development of occluded cell corrosion, the variation of current under different concentrations of $\mathrm{F}^{-}$are recorded at an applied voltage of $0.6 \mathrm{~V}(0.5 \%$ $\left.\left(\mathrm{NH}_{4}\right)_{2} \mathrm{SO}_{4}, 0.1 \mathrm{~mol} / \mathrm{L} \mathrm{Cl}^{-}\right)$, and the results are shown in Figure 6. At first, a general trend shows a slight rise, followed by a gradual decline, since the current is closely related to the surface area of the anode. With the continuous dissolution of the anode in the occluded cell, the exposed surface area of the anode tends to change. In the initial stage, the anode reaction area may increase slightly due to corrosion, leading to the increase of corrosion current. However, with the continuous dissolution of the anode, the surface area of the anode tends to decrease; thus, reducing the corrosion current. In $0.1 \mathrm{~mol} / \mathrm{L} \mathrm{Cl}^{-}$, i.e., the absence of $\mathrm{F}^{-}$, the corrosion current was large and decreased from the initial $57 \mathrm{~mA}$ to 
$36 \mathrm{~mA}$ as the reaction proceeded. As the concentration of $\mathrm{F}^{-}$in the solution increased, the corrosion current generally decreased. At a $\mathrm{F}^{-}$concentration greater than $0.2 \mathrm{~mol} / \mathrm{L}$, the current decreased significantly and remained at a low value. It can be concluded that $\mathrm{F}^{-}$ has a significant influence on the development of occluded cell corrosion, which is highly dependent on the $\mathrm{F}^{-}$concentration.

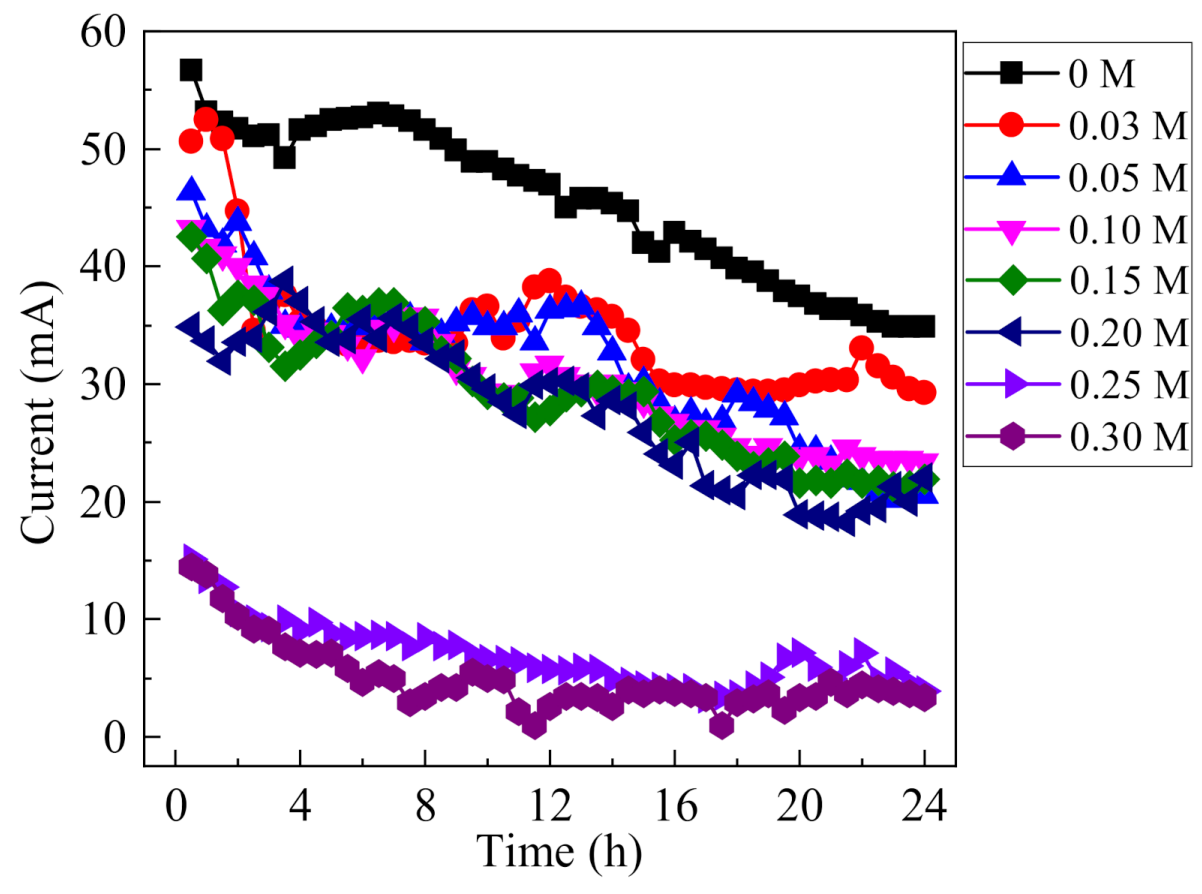

Figure 6. Variations of current as a function of $\mathrm{F}^{-}$concentration $\left(0.5 \%\left(\mathrm{NH}_{4}\right)_{2} \mathrm{SO}_{4}, 0.1 \mathrm{~mol} / \mathrm{L} \mathrm{Cl}^{-}\right.$, $0.6 \mathrm{~V})$.

Under an ideal electrochemical corrosion process, the relationship between the corrosion-related weight loss of stainless steel and the power consumption can be expressed as follows:

$$
\frac{\Delta W}{M_{r}} \cdot F \cdot Z=\int i d t
$$

where $\Delta W(\mathrm{~g})$ is weight loss, $M_{r}(\mathrm{~g} / \mathrm{mol})$ is the molar mass of iron, $\mathrm{Z}$ is the valence state of the iron ion, $F(\mathrm{C} / \mathrm{mol})$ is Faraday constant, $I(\mathrm{~A})$ is current, and $t(\mathrm{~s})$ is time.

The corresponding corrosion equivalent is calculated according to the weight loss of the stainless steel anode, and the results are shown in Figure 7. Meanwhile, the integral calculations of the occluded cell current under different $\mathrm{F}^{-}$concentrations (in Figure 6) were carried out, and the comparison of calculated actual power consumption with the corrosion equivalent is summarized in Figure 7. In the process of occluded cell corrosion, most of the energy consumed is used for metal corrosion, while a small part is lost in the system loop; thus, the corrosion equivalent and actual power consumption are not completely consistent. Figure 7 shows that with the increased concentration of $\mathrm{F}^{-}$, the corrosion equivalent and actual power consumption, both decrease gradually. For $\mathrm{F}^{-}$ concentrations less than $0.2 \mathrm{~mol} / \mathrm{L}$, i.e., $\mathrm{F}^{-} / \mathrm{Cl}^{-}$molar ratio $\leq 2$, the current tends to decrease with the increase of $\mathrm{F}^{-}$concentration; however, the decrease is small compared with the case without $\mathrm{F}^{-}$. For $\mathrm{F}^{-}$concentration greater than $0.2 \mathrm{~mol} / \mathrm{L}$, i.e., $\mathrm{F}^{-} / \mathrm{Cl}^{-}$molar ratio $>2$, the anodic corrosion current decreases rapidly. Then the corrosion current keeps stable when $\mathrm{F}^{-} / \mathrm{Cl}^{-}$molar ratio $>2$. As is known, the corrosion ratio is highly related with the corrosion current and the consumed power during the electrochemical corrosion process, so the reduction of power consumption with the increase of $\mathrm{F}^{-}$concentration shows that $\mathrm{F}^{-}$has an inhibition effect on the anodic corrosion in the occluded cell [24]. The obvious decrease of power consumption when $\mathrm{F}^{-} / \mathrm{Cl}^{-}$molar ratio $>2$ indicates 
that molar ratio $=2$ is the threshold molar ratio for the significant corrosion inhibition of stainless steel [9].

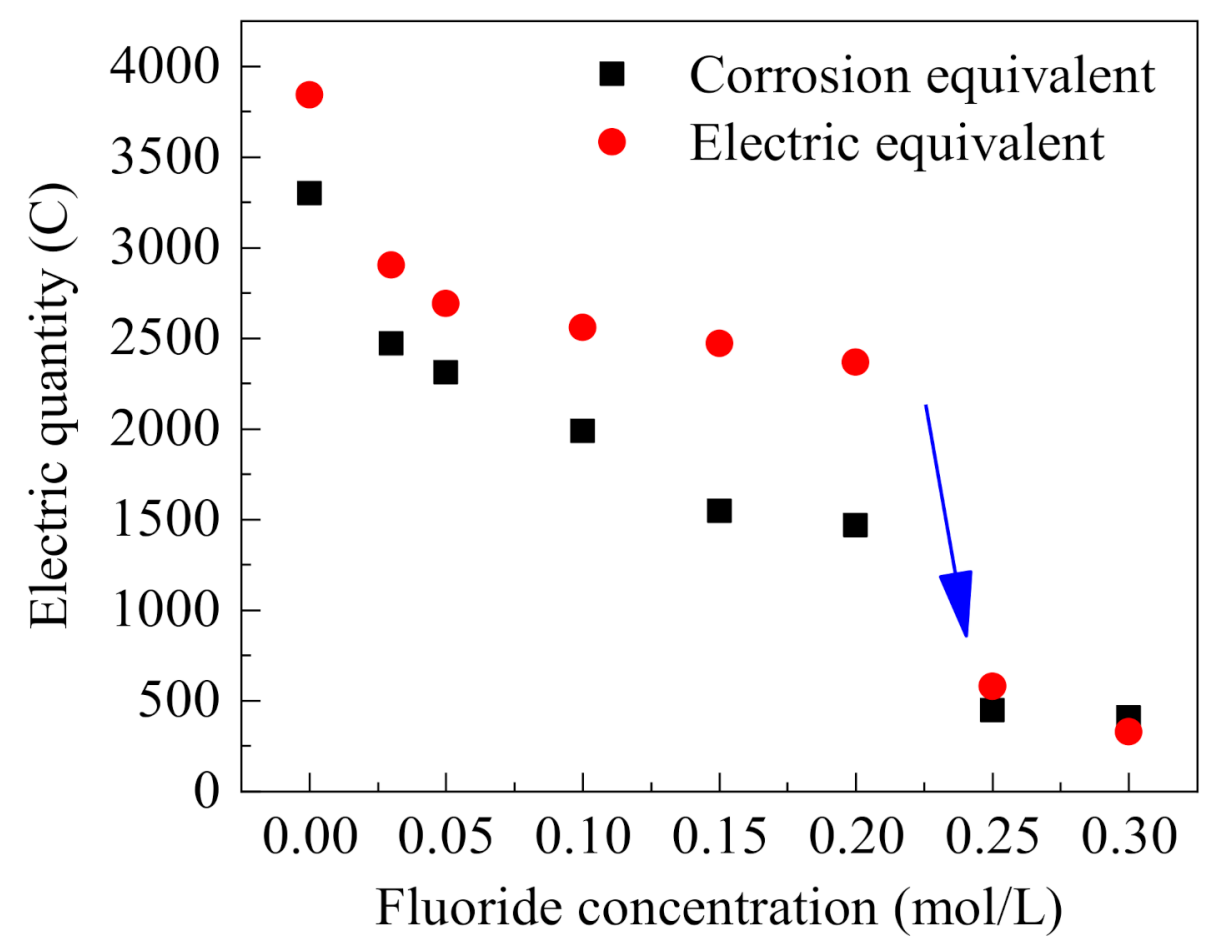

Figure 7. Corrosion and electric equivalent consumption under different $\mathrm{F}^{-}$concentrations $(0.5 \%$ $\left.\left(\mathrm{NH}_{4}\right)_{2} \mathrm{SO}_{4}, 0.1 \mathrm{~mol} / \mathrm{L} \mathrm{Cl}^{-}, 0.6 \mathrm{~V}\right)$.

\subsubsection{Influence of $\mathrm{F}^{-}$Concentration on the Migration of $\mathrm{Cl}^{-}$}

The concentration changes of $\mathrm{F}^{-}$and $\mathrm{Cl}^{-}$in the occlusion area with different $\mathrm{F}^{-}$ concentrations is shown in Figure 8. When the $\mathrm{F}^{-}$concentration is below $0.2 \mathrm{~mol} / \mathrm{L}$, the migrated amount of $\mathrm{F}^{-}$is negative; however, this result does not imply that the $\mathrm{F}^{-}$has not migrated. $\mathrm{F}^{-}$can combine with $\mathrm{H}^{+}$to form $\mathrm{HF}$, and $\mathrm{F}^{-}$can also combine with metal ions, so it no longer exists in an ionic state, both of which cannot be detected by the $\mathrm{F}^{-}$ion-selective electrode. When the concentration of $\mathrm{F}^{-}$is higher than $0.2 \mathrm{~mol} / \mathrm{L}$, the migration amount of $\mathrm{F}^{-}$increases significantly, indicating that a large amount of $\mathrm{F}^{-}$migrates from the external solution to the occlusion area. Meanwhile, with the increase of $\mathrm{F}^{-}$concentration, the concentration of $\mathrm{Cl}^{-}$in the occluded area tends to decrease continuously from $127.55 \mathrm{mmol} / \mathrm{L}$ to $26.91 \mathrm{mmol} / \mathrm{L}$, suggesting competitive migration between $\mathrm{F}^{-}$and $\mathrm{Cl}^{-}$. The hydration ion radii of $\mathrm{F}^{-}$and $\mathrm{Cl}^{-}$are close to each other, i.e., $0.352 \mathrm{~nm}$ and $0.332 \mathrm{~nm}$, respectively [29]. At the same time, $\mathrm{F}^{-}$is more electronegative than $\mathrm{Cl}^{-}$, so $\mathrm{F}^{-}$can pass through the rust layer into the occluded cell. When the concentration of $\mathrm{F}^{-}$is higher than $\mathrm{Cl}^{-}$, its migration is also higher, resulting in the reduction of $\mathrm{Cl}^{-}$migration.

The change of $\mathrm{pH}$ value can reflect the degree of acidification of the occluded solution, which is the key indicator of the corrosion development of the occluded cell. The $\mathrm{pH}$ changes in the occluded solution under different $\mathrm{F}^{-}$concentrations were analyzed, as shown in Figure 9. In the absence of $\mathrm{F}^{-}$, the $\mathrm{pH}$ value of the occluded solution stabilized to 2.7 under the action of acidification autocatalysis, which was consistent with previous studies [24]. With the increase of $\mathrm{F}^{-}$concentration, the final $\mathrm{pH}$ of the solution gradually increased, indicating that the acidification degree of the occluded solution gradually decreased. When the concentration of $\mathrm{F}^{-}$was greater than $0.2 \mathrm{~mol} / \mathrm{L}$, i.e., the $\mathrm{F}^{-} / \mathrm{Cl}^{-}$molar ratio was greater than 2 , the $\mathrm{pH}$ of the occluded solution did not decrease significantly within $24 \mathrm{~h}$. After migrating into the occluded solution, $\mathrm{F}^{-}$tends to combine with $\mathrm{H}^{+}$to form HF, which is a thermodynamically stable, weak acid [30]. The dissociation constant of 
$\mathrm{HF}(\mathrm{pKa}=3.17)$ is 13 orders of magnitude higher than that of $\mathrm{HCl}(\mathrm{pKa}=-8)$, i.e., $\mathrm{F}^{-}$has a strong ability to combine with $\mathrm{H}^{+}$. When $\mathrm{pH}<3, \mathrm{~F}^{-}$mainly exists in the form of $\mathrm{HF}$ or $\mathrm{HF}_{2}{ }^{-}$[31]. Thus, the concentration of $\mathrm{H}^{+}$tends to be reduced, and the decrease in $\mathrm{pH}$ of the solution can be inhibited; thus, effectively suppressing the acidification autocatalysis process in the occluded cell $[9,32]$.

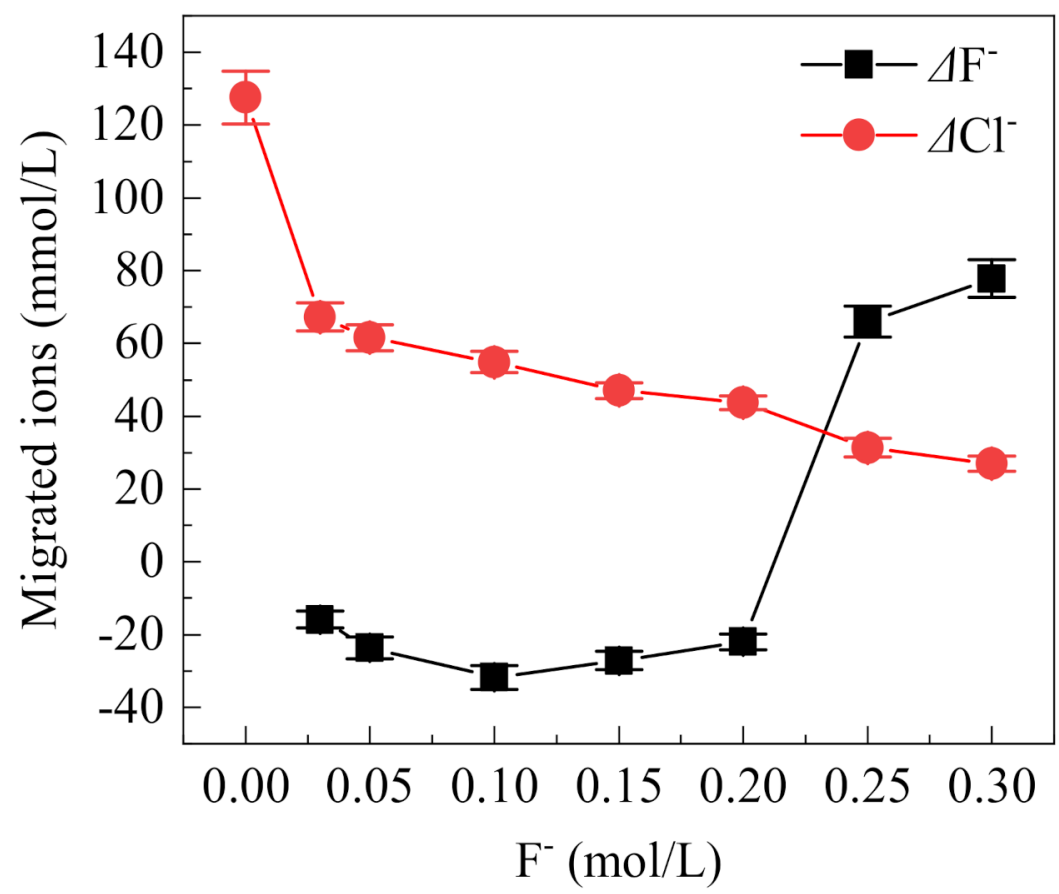

Figure 8. Migrated $\mathrm{F}^{-}$and $\mathrm{Cl}^{-}$in the occluded cell with different concentrations of $\mathrm{F}^{-}(0.5 \%$ $\left(\mathrm{NH}_{4}\right)_{2} \mathrm{SO}_{4}, 0.1 \mathrm{~mol} / \mathrm{L} \mathrm{Cl}^{-}$, the value is the difference of the final concentration and initial concentration of ions in the occluded cell).

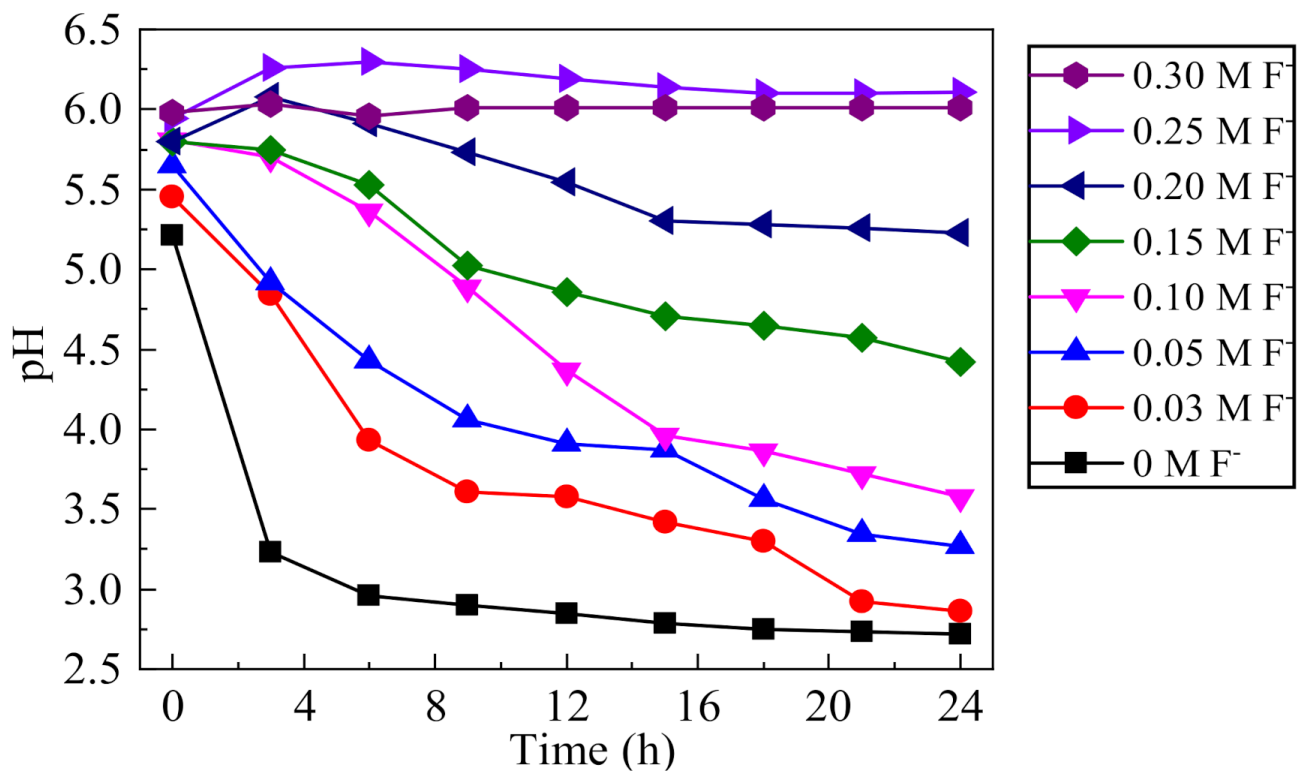

Figure 9. Effect of $\mathrm{F}^{-}$on the $\mathrm{pH}$ of occluded cell solution $\left(0.5 \%\left(\mathrm{NH}_{4}\right)_{2} \mathrm{SO}_{4}, 0.1 \mathrm{~mol} / \mathrm{L} \mathrm{Cl}^{-}\right)$. 


\subsubsection{XPS Analysis}

XPS was used to analyze the corrosion specimens inside the occluded area, and the results were compared with those of the blank specimens, as shown in Figure 10. The full spectrum shows that the characteristic peak of the element $F$ appears in the energy spectrum for the case containing $\mathrm{F}^{-}$(Figure 10a). This indicates that there are species containing $\mathrm{F}^{-}$, attached to the surface of the specimen after the reaction. By analyzing the energy spectrum of $\mathrm{F}$, it was found that the corrosion products have obvious characteristic peaks at binding energies $684.9 \mathrm{eV}$ and $684.2 \mathrm{eV}$, which can be attributed to metal fluorides such as $\mathrm{FeF}_{2}$ [33]. The energy spectra of the element Fe obtained from the corrosion products, and blank specimen have characteristic peaks at $711.5 \mathrm{eV}$ and $725.1 \mathrm{eV}$, which can be attributed to $\mathrm{Fe}_{2} \mathrm{O}_{3}$ [34]. The characteristic peaks at $714.3 \mathrm{eV}$ and $727.9 \mathrm{eV}$ in the energy spectra of the corrosion products, can be attributed to $\mathrm{FeF}_{2}$, combining with the $\mathrm{F}$ 1 s energy spectrum. The characteristic peaks of $\mathrm{FeF}_{2}$ are more obvious when $\mathrm{Fe} 2 \mathrm{p}$ spectra of specimens with and without $\mathrm{F}^{-}$are superimposed (insert in Figure 10c). The element $\mathrm{Cr}$ (Figure 10(d)) appears as characteristic peaks of $\mathrm{Cr} 2 \mathrm{p} 3 / 2$ at $577.4 \mathrm{eV}$ and $579.7 \mathrm{eV}$, where the former is attributed to $\mathrm{CrO}_{3}$, and the latter is attributed to $\mathrm{CrF}_{3}$. The $\mathrm{Cr} 2 \mathrm{p}$ energy spectrum $(587.5 \mathrm{eV})$ shifts towards a lower binding energy $(587.0 \mathrm{eV})$ when $\mathrm{F}^{-}$is existed in the solution (insert in Figure 10d), which may be due to the formation of fluoride. In conclusion, in the solution containing $\mathrm{F}^{-}, \mathrm{F}^{-}$can generate semi-soluble corrosion products with $\mathrm{Fe}$ and $\mathrm{Cr}$ (for example, $\mathrm{FeF}_{2}$ ) and attach to the surface of the stainless steel; thus, inhibiting the corrosion of steel.
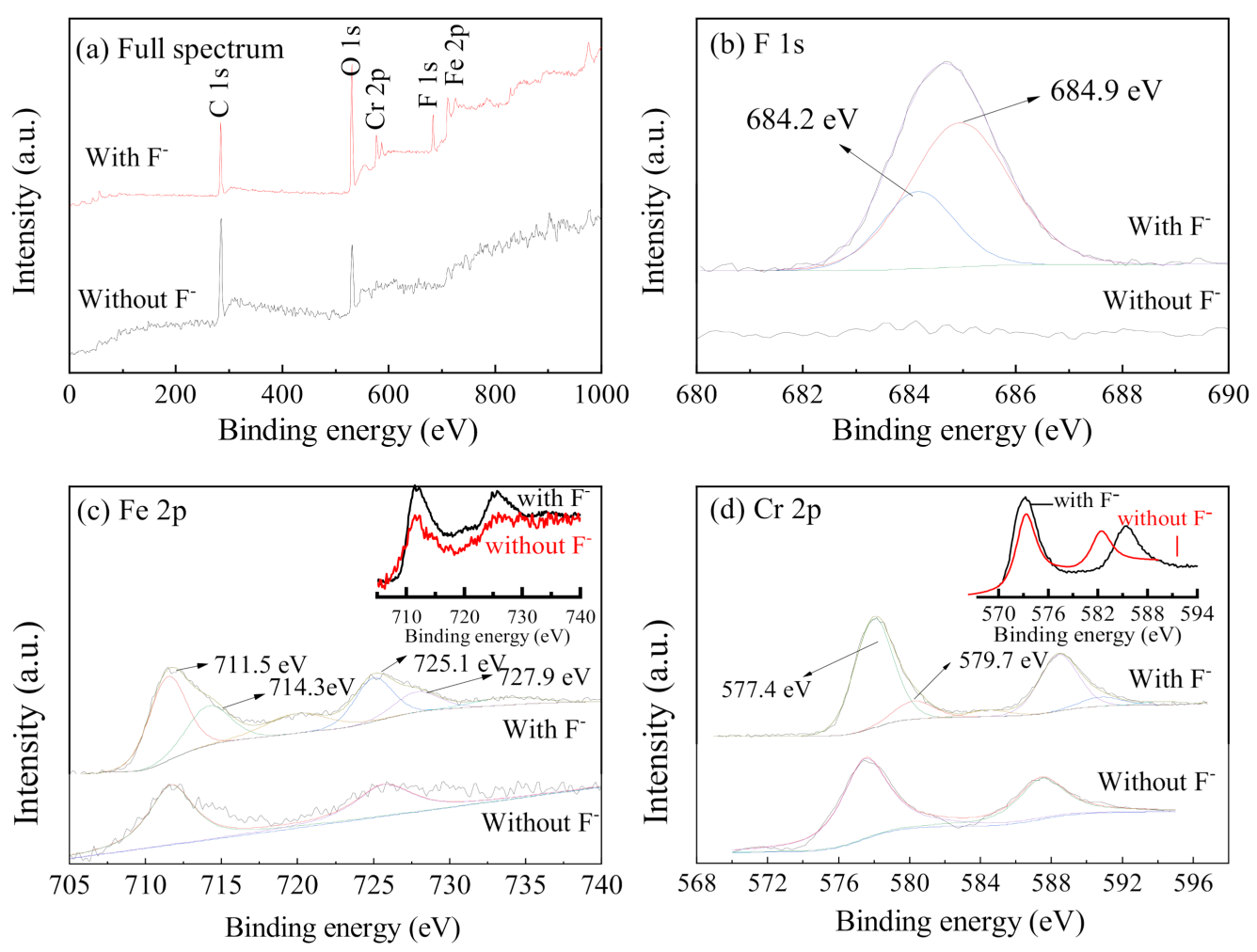

Figure 10. XPS spectra ((a) full spectrum, (b) F 1s, (c) Fe 2p, and (d) Cr 2p) of the specimens in the occluded area with and without $\mathrm{F}^{-}$(inserts in Figure 10c, d are the overlapped spectra of Fe 2p and $\mathrm{Cr} 2 \mathrm{p}$ with and without $\mathrm{F}^{-}$, respectively) $\left(0.5 \%\left(\mathrm{NH}_{4}\right)_{2} \mathrm{SO}_{4}, 0.1 \mathrm{~mol} / \mathrm{L} \mathrm{Cl}^{-}\right)$.

The XPS energy spectrum analysis was performed on the specimens with different $\mathrm{F}^{-}$concentrations, as shown in Figure 11. The concentration of $\mathrm{Cl}^{-}$was maintained at $0.1 \mathrm{~mol} / \mathrm{L}$ for all the cases, and $\mathrm{F}^{-}$concentration was varied as follows, $0,0.05,0.2$, and $0.3 \mathrm{~mol} / \mathrm{L}$. Combined with the XPS analysis from Figure 10, the characteristic peaks of Fe 2p3/2 at $707.5 \mathrm{eV}$ and $711.8 \mathrm{eV}$, can be attributed to elemental $\mathrm{Fe}$ and $\mathrm{Fe}_{2} \mathrm{O}_{3}$, respectively, in 
the absence of $\mathrm{F}^{-}$[35]. After the addition of $\mathrm{F}^{-}$, Fe tended to appear mainly as $\mathrm{Fe}_{2} \mathrm{O}_{3}$ and $\mathrm{FeF}_{2}$, with binding energies of $711 \mathrm{eV}$ and $714 \mathrm{eV}$, respectively. Additionally, $\mathrm{Cr}$ formed mainly $\mathrm{Cr}_{2} \mathrm{O}_{3}$ and $\mathrm{CrF}_{3}$, with binding energies of $577.4 \mathrm{eV}$ and $579.7 \mathrm{eV}$, respectively [36,37]. With the increase of $\mathrm{F}^{-}$concentration from 0.05 to $0.3 \mathrm{~mol} / \mathrm{L}$, the peak area of $\mathrm{F} 1 \mathrm{~s}$ first increased and then decreased, which could be attributed to the metal fluoride concentration. Firstly, with the increase in $\mathrm{F}^{-}$concentration, the reaction of $\mathrm{F}^{-}$with metal ions tends to increase, and the amount of metal fluoride attached to the surface of the specimens also increases. As $\mathrm{F}^{-}$concentration continues to increase, corrosion tends to be inhibited, and hydrolysis of metal in the occluded area slows to a certain extent. Thus, the metal ion concentration decreases, and the metal fluoride generated is slightly reduced.
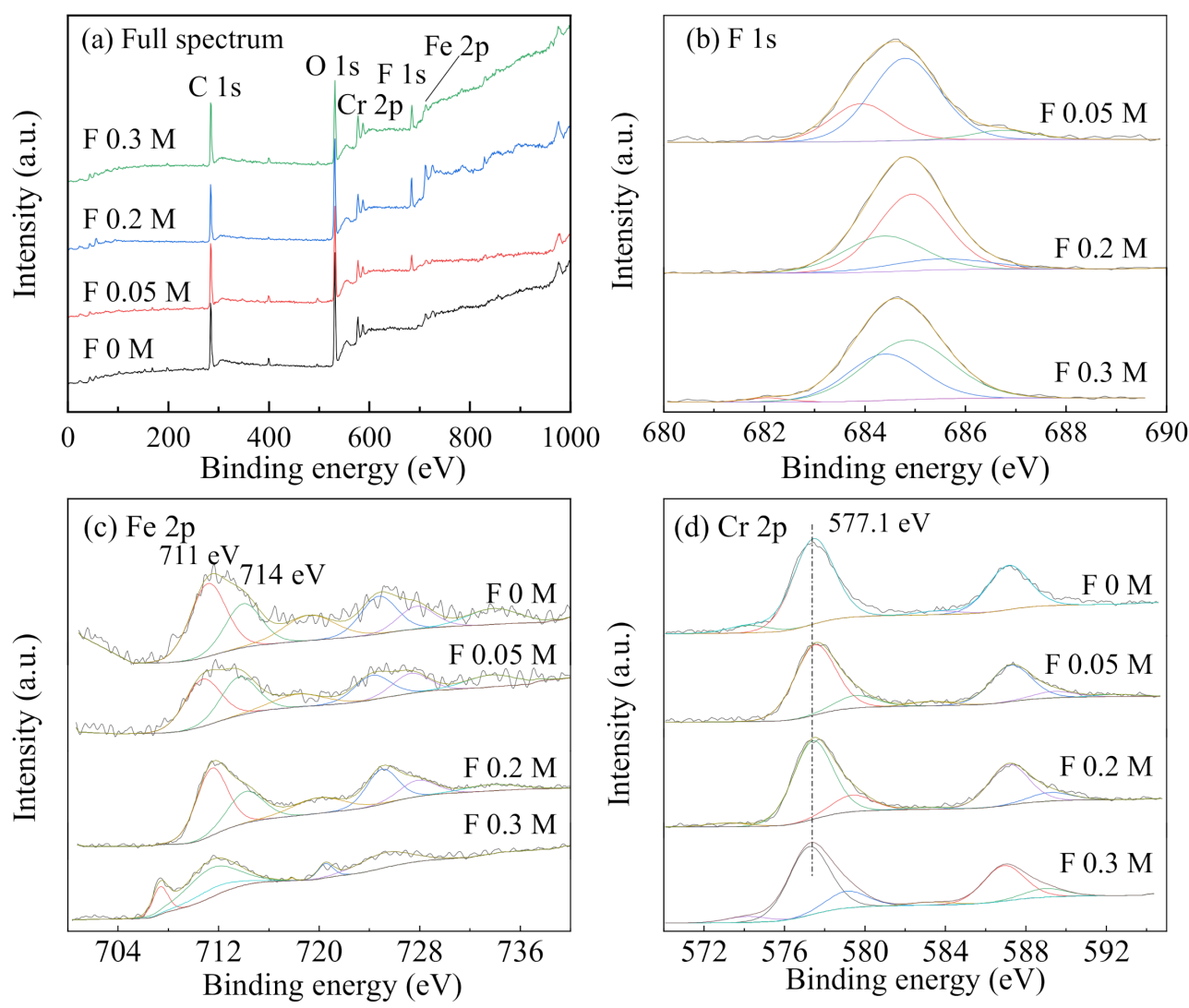

Figure 11. XPS spectra ((a) full spectrum, (b) F 1s, (c) Fe 2p, and (d) Cr 2p) of the corrosion products on stainless steel specimens at different $\mathrm{F}^{-}$concentrations at a fixed $\mathrm{Cl}^{-}$concentration of $0.1 \mathrm{~mol} / \mathrm{L}$.

\subsection{Influence of $F^{-}$on the Corrosion of Drilled Holes for the Simulation of Occluded Cells}

To investigate the influence of $\mathrm{F}^{-}$on the internal corrosion rate of the simulated block cell, different concentrations of $\mathrm{F}^{-}$were added to the simulated desulfurization slurry with $0.5 \%\left(\mathrm{NH}_{4}\right)_{2} \mathrm{SO}_{4}$ and $\mathrm{Cl}^{-}$concentrations of $0.01,0.05$, and $0.5 \mathrm{~mol} / \mathrm{L}$. Figure $12 \mathrm{a}-\mathrm{c}$ shows that with the increase in the concentration of $\mathrm{Cl}^{-}$, the corrosion rate in the drilled hole increases, indicating aggravated corrosion in the occluded area [7]. When the concentration of $\mathrm{Cl}^{-}$is $0.01 \mathrm{~mol} / \mathrm{L}$ (Figure 12a), the corrosion rate tends to increase with the increase in $\mathrm{F}^{-}$concentration, reaching a maximum at $0.04 \mathrm{~mol} / \mathrm{L}$. Subsequently, the corrosion rate gradually decreases with the increase of $\mathrm{F}^{-}$concentration and is lower than that obtained in the absence of $\mathrm{F}^{-}$. For $\mathrm{Cl}^{-}$concentrations of 0.05 and $0.1 \mathrm{~mol} / \mathrm{L}$ (Figure $12 \mathrm{~b}, \mathrm{c}$, respectively), the corrosion rate in the drilled hole changes with the increase of concentration of $\mathrm{F}^{-}$, which is approximately the same trend. When the corrosion rate is lower than that for the case without $\mathrm{F}^{-}$, i.e., when the corrosion in the drilled holes is inhibited, the molar ratios of $\mathrm{F}^{-}$and $\mathrm{Cl}^{-}$are 20,16, and 15, in the three cases, indicating that the inhibition of $\mathrm{F}^{-}$is not only related to the ratio of the two ions but also related to the concentration 
of $\mathrm{Cl}^{-}$[9]. Compared with the experimental results of the simulated occluded cell, the corrosion rate in the borehole tends to increase instead of consistently decreasing when a small amount of $\mathrm{F}^{-}$was added to the solution. At the same time, the molar ratio of $\mathrm{F}^{-}$to $\mathrm{Cl}^{-}$was higher than that of the simulated occluded cell $\left(\mathrm{F}^{-} / \mathrm{Cl}^{-}>2\right)$, when the corrosion was significantly inhibited. The simulated occluded cell was powered by a potentiostat, and a stable voltage was supplied, to continue the process of corrosion, which was seen to take place spontaneously inside the borehole. For the case of a low concentration $\mathrm{F}^{-}$, the solution conductance tends to increase, which promotes corrosion. Thus, corrosion inhibition only takes place in the case of high concentrations of $\mathrm{F}^{-}$.
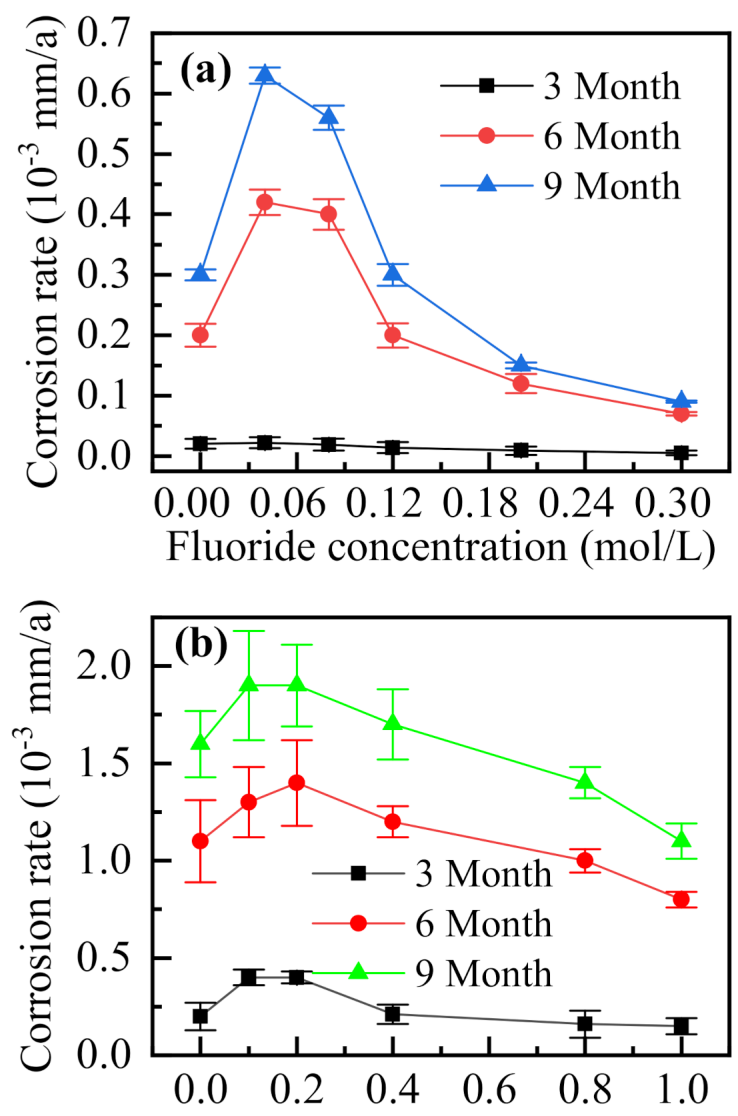

Fluoride concentration $(\mathrm{mol} / \mathrm{L})$

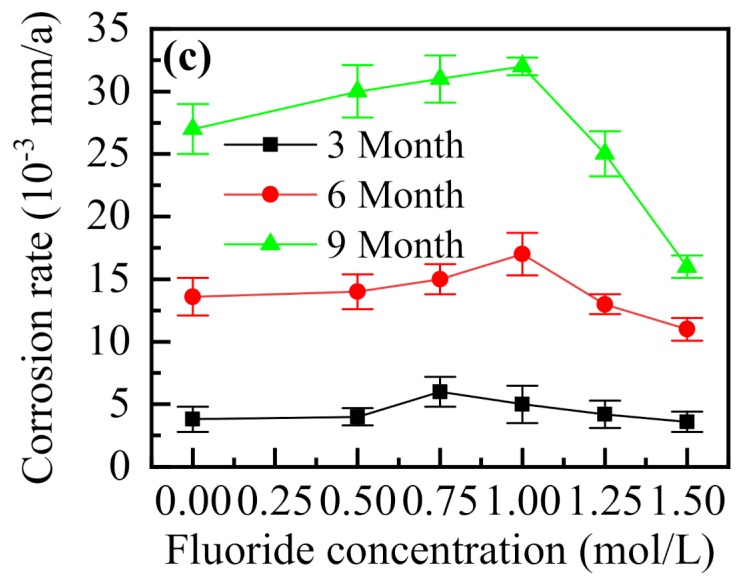

Figure 12. $\mathrm{F}^{-}$concentration-dependent variations of the corrosion rate in the drilled hole under $\mathrm{Cl}^{-}$ concentrations of (a) 0.01 , (b) 0.05 , and (c) $0.1 \mathrm{~mol} / \mathrm{L}\left(0.5 \%\left(\mathrm{NH}_{4}\right)_{2} \mathrm{SO}_{4}\right)$. 
In conclusion, the $\mathrm{F}^{-}$shows an inhibitory effect on the propagation of localized occluded cell corrosion of 304 stainless steel in the presence of $\mathrm{Cl}^{-}$. As shown in Scheme 1a, when $\mathrm{Cl}^{-}$solely exists and migrates into the occluded area through rust layer, the propagation of occluded area follows the acidification autocatalytic process. When $\mathrm{F}^{-}$and $\mathrm{Cl}^{-}$ coexists (Scheme $1 \mathrm{~b}$ ), $\mathrm{F}^{-}$shows an obvious inhibition effect on the localized corrosion at occluded cell corrosion stage, the reasons are as follows: (1) There is competitive migration between $\mathrm{F}^{-}$and $\mathrm{Cl}^{-}$, and high concentration of $\mathrm{F}^{-}$can reduce the migration of $\mathrm{Cl}^{-}$; thus, inhibiting the acidification autocatalytic process mediated by $\mathrm{Cl}^{-} ;(2)$ after migrating into the occluded area, $\mathrm{F}^{-}$tends to combine with $\mathrm{H}^{+}$in the occluded solution to form a thermodynamically stable weak acid $\mathrm{HF}$, reducing the concentration of $\mathrm{H}^{+}$and preventing the $\mathrm{pH}$ value from becoming too low; and (3) $\mathrm{F}^{-}$tends to react with metal ions and form semi-soluble $\mathrm{FeF}_{2}$ and $\mathrm{CrF}_{3}$, which are attached on the inner surface of occluded area to prevent further corrosion. The coupling of the above mechanisms resulted in the inhibition of the corrosion in occluded area.

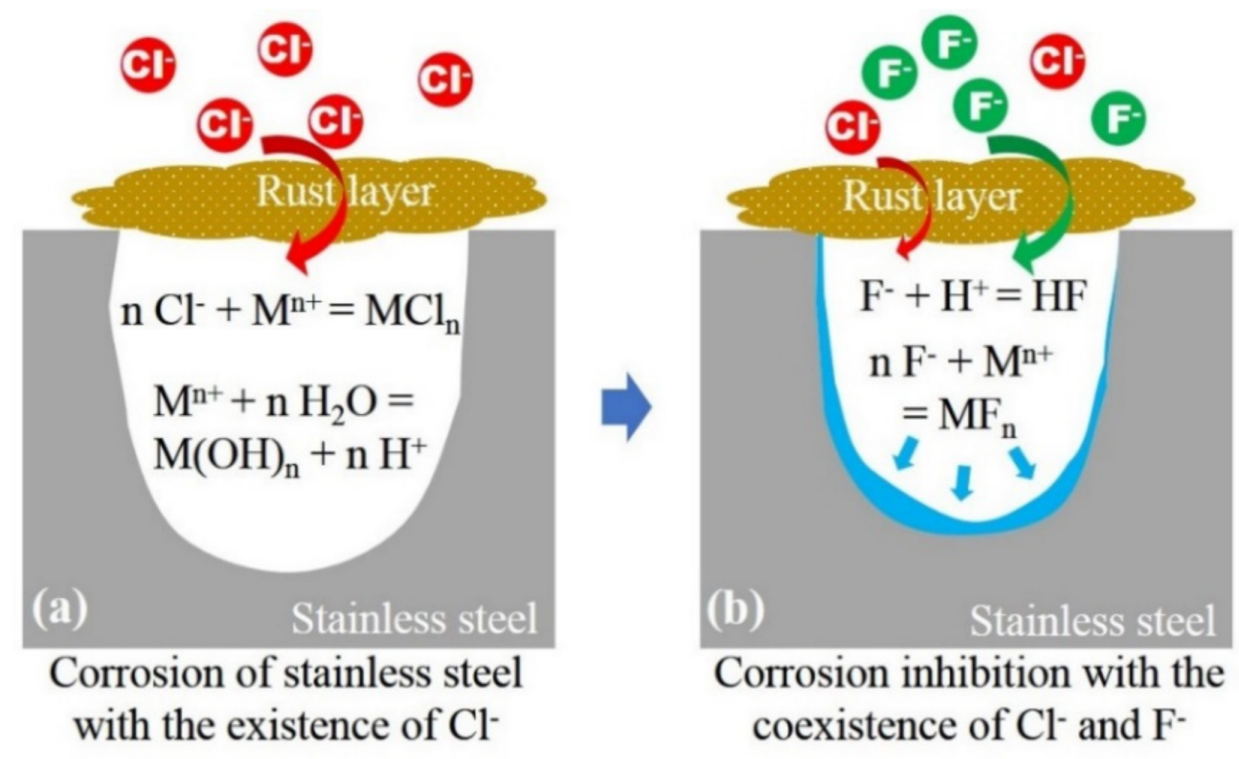

Scheme 1. (a) Corrosion propagation of stainless steel with the existence of $\mathrm{Cl}^{-}$and (b) the inhibition mechanism of $\mathrm{F}^{-}$with the coexistence of $\mathrm{Cl}^{-}$.

\section{Conclusions}

The influence of $\mathrm{F}^{-}$on the development of localized corrosion of 304 stainless steel in the occluded cell corrosion stage has been investigated using a simulated occluded corrosion cell and drilled specimens. By using the present simulated occluded corrosion cell, it can be concluded that when the $\mathrm{F}^{-}$concentration is higher than $0.2 \mathrm{~mol} / \mathrm{L}$, i.e., $\mathrm{F}^{-} / \mathrm{Cl}^{-}$molar ratio $>2$, the corrosion current drops sharply, and the corrosion rate significantly decreases. The results demonstrated that the corrosion of the occluded cell of 304 stainless steel could be inhibited by $\mathrm{F}^{-}$, and the localized corrosion in the propagation stage could be restrained due to the reduction of migrated $\mathrm{Cl}^{-}$in occluded area caused by the competitive migration of $\mathrm{F}^{-}$, alleviating of acidification in occluded area through the combination of $\mathrm{F}^{-}$with $\mathrm{H}^{+}$, and the formation of protective semi-soluble films by $\mathrm{F}^{-}$ and metallic ions. For the borehole simulation experiment, the corrosion inhibition of $\mathrm{F}^{-}$ is verified, even the influence of $\mathrm{F}^{-}$on the corrosion in the drilled holes is different from that of simulated occluded area. It is indicated that the simulated occluded cell model adopted in this study can partly restore the actual corrosion situation, which has practical application and significance for processes involving localized corrosion in metals and needs further investigation. 
Author Contributions: Conceptualization, Z.L. (Zhengwei Luo), Z.L. (Zhouyang Lian) and W.W.; data curation, J.Z. and H.J.; formal analysis, Z.L. (Zhengwei Luo), H.J. and W.G.; funding acquisition, W.W.; investigation, J.Z. and Y.Z.; methodology, Z.L. (Zhengwei Luo) and W.W.; project administration, W.W.; resources, Z.L. (Zhouyang Lian) and W.W.; supervision, Z.L. (Zhouyang Lian) and W.W.; writing-original draft, Z.L. (Zhengwei Luo); writing-review \& editing, Z.L. (Zhengwei Luo), Z.L. (Zhouyang Lian) and W.W. All authors have read and agreed to the published version of the manuscript.

Funding: This research was funded by the National Natural Science Foundation of China, grant number 21676144.

Institutional Review Board Statement: Not applicable.

Informed Consent Statement: Not applicable.

Data Availability Statement: Not applicable.

Conflicts of Interest: The authors declare no conflict of interest.

\section{References}

1. Alvarez-Ayuso, E.; Querol, X. Stabilization of FGD gypsum for its disposal in landfills using amorphous aluminium oxide as a fluoride retention additive. Chemosphere 2007, 69, 295-302. [CrossRef] [PubMed]

2. Buryan, P.; Vejvoda, J.; Skácel, F.; Tekáč, V. Chlorine balance at brown coal combustion and flue gas desulfurization. Pol. J. Environ. Stud. 2008, 17, 687-692.

3. Wang, G.; Luo, Z.; Zhang, J.; Zhao, Y. Modes of occurrence of fluorine by extraction and SEM method in a coal-fired power plant from Inner Mongolia, China. Minerals 2015, 5, 863-869. [CrossRef]

4. Lian, Z.; Luo, Z.; Yuan, L.; Wei, W. Corrosion investigation of ammonia flue gas desulfurization. Mater. Perform. 2016, 55, 50-53.

5. Borgioli, F. From austenitic stainless steel to expanded austenite-S phase: Formation, characteristics and properties of an elusive metastable phase. Metals 2020, 10, 187. [CrossRef]

6. Tzaneva, B.R.; Fachikov, L.B.; Raicheff, R.G. Effect of halide anions and temperature on initiation of pitting in Cr-Mn-N and Cr-Ni steels. Br. Corros. J. 2006, 41, 62-66. [CrossRef]

7. Zhu, J.; Fan, Z.; Xu, L. On the propagation of a single pit in stainless steel. Appl. Surf. Sci. 2020, 511, 145624. [CrossRef]

8. Mirjalili, M.; Momeni, M.; Ebrahimi, N.; Moayed, M.H. Comparative study on corrosion behaviour of Nitinol and stainless steel orthodontic wires in simulated saliva solution in presence of fluoride ions. Mater. Sci. Eng. C-Mater. 2013, 33, 2084-2093. [CrossRef]

9. Carranza, R.M.; Rodríguez, M.A.; Rebak, R.B. Effect of fluoride ions on crevice corrosion and passive behavior of alloy 22 in hot chloride solutions. Corrosion 2007, 63, 480-490. [CrossRef]

10. Wang, Z.B.; Hu, H.X.; Zheng, Y.G. Synergistic effects of fluoride and chloride on general corrosion behavior of AISI 316 stainless steel and pure titanium in $\mathrm{H}_{2} \mathrm{SO}_{4}$ solutions. Corros. Sci. 2018, 130, 203-217. [CrossRef]

11. Marcelin, S.; Pébère, N.; Régnier, S. Electrochemical characterisation of a martensitic stainless steel in a neutral chloride solution. Electrochim. Acta 2013, 87, 32-40. [CrossRef]

12. Marcelin, S.; Pébère, N.; Régnier, S. Electrochemical investigations on crevice corrosion of a martensitic stainless steel in a thin-layer cell. J. Electroanal. Chem. 2015, 737, 198-205. [CrossRef]

13. Percheron, A.; Vuillemin, B.; Oltra, R.; Markey, L. Mapping of $\mathrm{pH}$ gradients in a micrometric occluded cell: Comparison with a pseudo-2D transport model. J. Appl. Electrochem. 2010, 41, 355-361. [CrossRef]

14. Kaji, T.; Sekiai, T.; Muto, I.; Sugawara, Y.; Hara, N. Visualization of $\mathrm{pH}$ and $\mathrm{pCl}$ distributions: Initiation and propagation criteria for crevice corrosion of stainless steel. J. Electrochem. Soc. 2012, 159, C289-C297. [CrossRef]

15. Miyamoto, K.; Sakakita, S.; Wagner, T.; Schöning, M.J.; Yoshinobu, T. Application of chemical imaging sensor to in-situ pH imaging in the vicinity of a corroding metal surface. Electrochim. Acta 2015, 183, 137-142. [CrossRef]

16. Galvele, J.R. Transport processes and the mechanism of pitting of metals. J. Electrochem. Soc. 1976, 123, 464. [CrossRef]

17. Jingyi, Z.; Pourbaix, M.; Chunchun, X.; Youping, L. Kinetic and thermodynamic behaviour inside occluded corrosion cells interpreted by potential/pH diagrams. Corros. Sci. 1989, 29, 557-566. [CrossRef]

18. Pérez-Brokate, C.F.; di Caprio, D.; Féron, D.; de Lamare, J.; Chaussé, A. Three dimensional discrete stochastic model of occluded corrosion cell. Corros. Sci. 2016, 111, 230-241. [CrossRef]

19. Perdomo, J.J.; Song, I. Chemical and electrochemical conditions on steel under disbonded coatings: The effect of applied potential, solution resistivity, crevice thickness and holiday size. Corros. Sci. 2000, 42, 1389-1415. [CrossRef]

20. Zhu, Z.; Liu, X.; Ye, Z.; Zhang, J.; Cao, F.; Zhang, J. A fabrication of iridium oxide film pH micro-sensor on Pt ultramicroelectrode and its application on in-situ $\mathrm{pH}$ distribution of $316 \mathrm{~L}$ stainless steel corrosion at open circuit potential. Sens. Actuators B Chem. 2018, 255, 1974-1982. [CrossRef]

21. Lin, C.; Du, R.; Nguyen, T. In-Situ imaging of chloride ions at the metal/solution interface by scanning combination microelectrodes. Corrosion 2000, 56, 41-47. [CrossRef] 
22. Yan, M.; Sun, C.; Xu, J.; Wu, T.; Yang, S.; Ke, W. Stress corrosion of pipeline steel under occluded coating disbondment in a red soil environment. Corros. Sci. 2015, 93, 27-38. [CrossRef]

23. Yan, M.C.; Wang, J.Q.; Han, E.H.; Ke, W. Electrochemical measurements using combination microelectrode in crevice simulating disbonded of pipeline coatings under cathodic protection. Corros. Eng. Sci. Technol. 2007, 42, 42-49. [CrossRef]

24. Zhu, Y.; Qiu, Y.; Guo, X. Underscale corrosion behavior of carbon steel in a $\mathrm{NaCl}$ solution using a new occluded cavity cell for simulation. J. Appl. Electrochem. 2009, 39, 1017-1023. [CrossRef]

25. Zhu, Y.; Guo, X.; Qiu, Y. Inhibition mechanism of sodium laurate to underdeposit corrosion of carbon steels in $\mathrm{NaCl}$ solutions. Br. Corros. J. 2013, 45, 442-448. [CrossRef]

26. Luo, Z.; Guo, M.; Chen, H.; Lian, Z.; Wei, W. Determining fluoride ions in ammonium desulfurization slurry using an ion selective electrode method. IOP Conf. Ser. Earth Environ. Sci. 2018, 121, 22033. [CrossRef]

27. Liu, J.; Jiang, Z.; Zhao, Y.; Zhou, H.; Wang, X.; Zhou, H.; Xing, F.; Li, S.; Zhu, J.; Liu, W. Chloride distribution and steel corrosion in a concrete bridge after long-term exposure to natural marine environment. Materials 2020, 13, 3900. [CrossRef] [PubMed]

28. Torres, C.; Iannuzzi, M.; Johnsen, R. Use of the critical acidification model to estimate the influence of W in the localized corrosion resistance of 25Cr super duplex stainless steels. Metals 2020, 10, 1364. [CrossRef]

29. Li, Y.; Xu, T. Permselectivities of monovalent anions through pyridine-modified anion-exchange membranes. Sep. Purif. Technol. 2008, 61, 430-435. [CrossRef]

30. Pahlavan, S.; Moazen, S.; Taji, I.; Saffar, K.; Hamrah, M.; Moayed, M.H.; Beidokhti, S.M. Pitting corrosion of martensitic stainless steel in halide bearing solutions. Corros. Sci. 2016, 112, 233-240. [CrossRef]

31. Wang, Z.B.; Hu, H.X.; Zheng, Y.G. Evaluation of the dissolved oxygen-related electrochemical behavior of pure titanium in acidic fluoride-containing solutions. J. Solid State Electr. 2016, 20, 3459-3471. [CrossRef]

32. Mariano, A.K. Localized corrosion and stress corrosion cracking of stainless steels in halides other than chlorides solutions: A review. Corros. Rev. 2020, 38, 1-24.

33. Alexander, V.N.; Anna, K.; Stephen, W.G.; Powell, C.J. NIST X-ray Photoelectron Spectroscopy Database, NIST Standard Reference Database Number 20; U.S. Department of Commerce, National Institute of Standards and Technology: Gaithersburg, MD, USA, 2000.

34. Xiang, Y.; Song, C.; Li, C.; Yao, E.; Yan, W. Characterization of 13Cr steel corrosion in simulated EOR-CCUS environment with flue gas impurities. Process Saf. Environ. 2020, 140, 124-136. [CrossRef]

35. Kumagai, M.; Myung, S.; Asaishi, R.; Katada, Y.; Yashiro, H. High nitrogen stainless steel as bipolar plates for proton exchange membrane fuel cells. J. Power Sources 2008, 185, 815-821. [CrossRef]

36. Maurice, V.; Yang, W.P.; Marcus, P. X-ray photoelectron spectroscopy and scanning tunneling microscopy study of passive films formed on (100) Fe-18Cr-13Ni single-crystal surfaces. J. Electrochem. Soc. 1998, 145, 909. [CrossRef]

37. Huang, C.; Shih, C. Effects of nitrogen and high temperature aging on $\sigma$ phase precipitation of duplex stainless steel. Mater. Sci. Eng. A Struct. 2005, 402, 66-75. [CrossRef] 